\title{
Herpes Zoster associated With COVID-19 in an immunocompetent male
}

\author{
Faruk $\mathrm{AA}^{1^{*}}$ Rahman $\mathrm{MR}^{2}$
}

\section{AFFILIATION:}

1. Abdullah Al Faruk

Assistant Professor, Department of Medicine,

East West Medical College, Dhaka, Bangladesh.

Tel: +8801712265035

Email: farukdoctor@gmail.com

2. Mohammad Rifat Rahman

Assistant register, Department of Medicine,

East West Medical College, Dhaka. Bangladesh.

Tel: +8801737933022

Rifat614@gmail.com

Article info.

Received: 09 April 2021

Accepted: 17 July 2021

Volume: Vol-11, Issue-2, October 2021

DOI: https://doi.org/10.3329/updcj.v11i2.56096

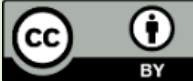

(C) Authors retain copyright and grant the journal right of first publication with the work simultaneously licensed under Creative Commons Attribution License CC - BY 4.0 that allows others to share the work with an acknowledgment of the work's authorship and initial publication in this journal.

https://creativecommons.org/licenses/by/4.0/

Publisher: Update Dental College, Dhaka, Bangladesh

Web: www.updatedentalcollege.edu.bd

E-mail: updcj@hotmail.com

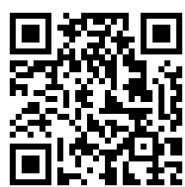

Scan QR code to see the latest issue

* Corresponding Author Abdullah Al Faruk

Assistant Professor, Department of Medicine,

East West Medical College, Dhaka, Bangladesh Tel: +8801712265035

Email: farukdoctor@gmail.com
ABSTRACT:

Severe acute respiratory syndrome coronavirus (SARS-COV-2) presented with pulmonary symptoms and various extra pulmonary manifestations including dermatological manifestations like urticarial, acralvascular lesion erythematous maculopapular rash, and vesicular rash. Herpes zoster is a painful vesicular rash resulting from reactivation of varicella-zoster (VZ) virus that also a causative agent of chickenpox. The incidence of $\mathrm{HZ}$ infection (HZI) more prevalent in older ages and various immunosuppressive conditions. Coronavirus disease in 2019(Covid19) causing immune exhaustion and VZ virus reactivation, which is commonly presented as $\mathrm{HZ}$ in middle-aged adults. Here we report a case of $\mathrm{HZ}$ infection in association with COVID 19 positive 60 years male.

KEYWORDS: co-infection; corona virus disease; covid-19; valaciclovir; herpes zoster; immunocompetent; immunosuppressant; novel corona virus; sarscov-2; varicella-zoster virus.

\section{INTRODUCTION:}

Severe acute respiratory syndrome coronavirus 2 (SARS-CoV2) was identified in December 2019 as the cause of COVID-19 in Wuhan City in Hubei Province, China [1]. The first case of a COVID-19 patient was detected in Bangladesh on 8th March 2020 [2]. The high infectivity and the rapid transmission characteristics of the virus led to an epidemic throughout china followed by a pandemic that is affecting a large number of people all over the world [3]. Initially, the transmission of SARS-CoV2 was considered as a zoonotic transmission associated with the seafood market in Wuhan, China. Later on, human-to-human transmission through respiratory droplets and secretions was recognized to play a major role in the significant outbreak [3].SARS-CoV2 is an enveloped, singlestranded RNA virus that belongs to the coronavirus family [4]. Cell entry is believed to be through the angiotensin-converting enzyme 2 (ACE2) receptors found on the surface of the cells [4]. Patients with COVID-19 can be asymptomatic or may show mild, moderate and severe cases and eventually lead to the fatal outcome.

Sachdeva $M$, Gianotti $R$, Shah $M$, et al state a variety of dermatological manifestations were documented in COVID-19 cases. Morbilliform rashes or maculopapular exanthema were the most common, followed by a papulovesicular rash, urticaria, and other cutaneous signs [4]. $\mathrm{HZ}$ is an acute viral illness that is presented after the reactivation of the varicellazoster virus (VZV) that usually remains dormant within the dorsal root ganglion [5]. $\mathrm{HZ}$ usually appears when the immune system fails to contain the latent VZV replication. Therefore, it often occurs in the elderly and is more frequent in severely immunocompromised conditions. Other factors like trauma, radiation, drugs, and stress but have not been determined with certainty [6]. Here, we presented a case of an immunocompetent adult male who visited for COVID -19 and later exhibited herpes zoster infection 


\section{CASE PRESENTATION:}

A 60-years-old male, known case of hypertension, smoker presented to OPD with a three-day history of high-grade fever with chills, dry cough, chest discomfort, and severe myalgia. The COVID-19 screening test was arranged and the patient was treated symptomatically and advised for home isolation. The next day, his nasopharyngeal swab for rt-PCR turned positive for SARS-CoV2, and the patient was advised for supervised treatment. On the $6^{\text {th }}$ day of his illness, he reported onset itch and painful rash over the back of his neck that started suddenly. The patient states that the rash is fluid-filled bubbles that rupture upon scratching releasing colorless discharges. Vital signs and physical examination were normal except for vesicles with surrounding erythema affecting the back of the neck. The rash Involving C3 Dermatome unilateral on the right side of the neck without crossing the midline supporting the diagnosis of $\mathrm{HZ}$. Initial blood tests were unremarkable apart from elevated C-reactive protein $(121 \mathrm{mg} / \mathrm{L}$, normal range 0 $10 \mathrm{mg} / \mathrm{L})$, estimated sedimentation rate $(100 \mathrm{~mm} / \mathrm{hr}$., 0 $10 \mathrm{~mm} / \mathrm{hr}$.) and elevated D-dimer $(1.26 \mathrm{mcg} / \mathrm{ml}$, normal range 0-0.5 mcg/ml). HRCT of the chest shows multi-focal groundglass opacities, interlobular thickening with crazy paving appearance involving a different segment of both lungs.
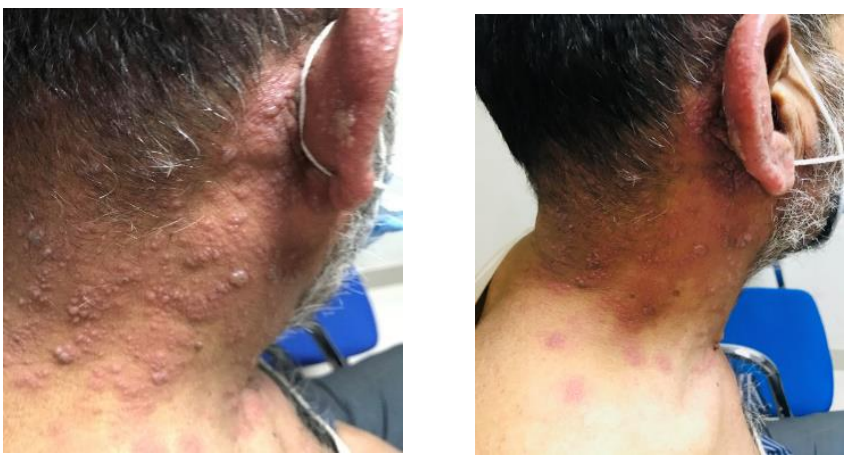

Fig 1: (Left side) Multiple vesicles with surrounding erythema involving C3 distribution of right side of the neck. Fig 2: (Right side) Multiple vesicles with surrounding erythema involving $\mathrm{C3}$ distribution of right side of the neck

He was treated with board spectrum antibiotic, LMWH, Montelukast and bronchodilator for Covid pneumonia however for $\mathrm{HZ}$, he was prescribed valaciclovir $1 \mathrm{gm}$ TDS for 7 days. Since starting medication his respiratory symptoms and $\mathrm{HZ}$ rash significantly improved with residual pain at the $\mathrm{HZ}$ site.

\section{DISCUSSION:}

Reactivation of latent VZV in dorsal-root ganglia leads to Infection. The virus causing neural damage through migration along a particular sensory nerve and subsequently, a vesicular rash emerges in the affected dermatome [7]. Typically, before rash appearance, the most patient experiencing a preparatory itching, or painful sensation followed by vesicles pustulate. Increasing age is considered the most crucial individual risk 36| $\mathrm{P}$ a g e

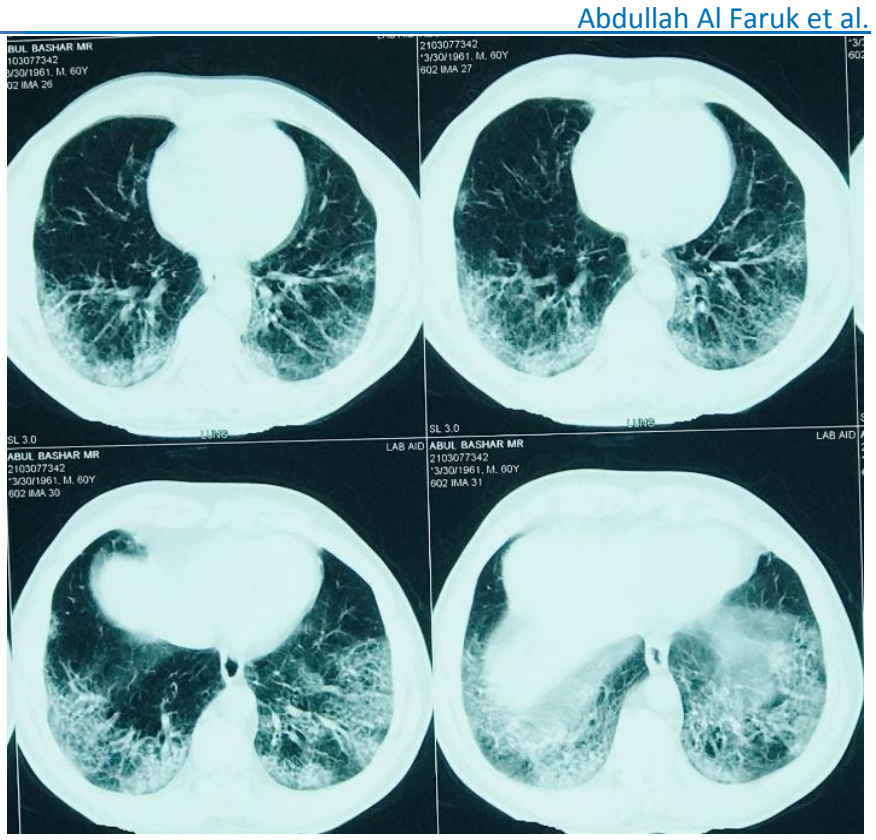

Fig 3: HRCT of the chest shows multifocal ground-glass opacities, interlobular thickening with crazy paving appearance involving a different segment of both lungs.

factor for $\mathrm{HZ}$. After acquiring a VZV infection, the T-cell immunity level starts to decline resulting in a reduction in immunity against $\mathrm{HZ}$ [8]. Other conditions like patients who receiving immunosuppressive medications and those suffering from HIV infection or certain hematological malignancy also create a low T-cell level environment [9]. However, our case represented a relatively younger without risk factors insinuating a low immunity status; nonetheless, he had contracted COVID-19. In COVID-19, the minority of cases presented with severe symptoms and a hyper-inflammatory state [10]. Cytokine storm develops within few days, in addition to an extreme complement and innate immune activation. Excessive stimulation intensifies the inflammatory response, producing molecular dysregulation [11]. Progression of the hyperactive immune state consequently causes immune cell dysfunction [12]. These outcomes create optimum habitat for $\mathrm{HZ}$ emergence. Unlike our case, patients with severe COVID where the disease manifested drastic immunosuppression, presented with severe symptoms [13]. Nevertheless, observations on patients with mild disease have illustrated significantly decreased $\mathrm{T}$ cell and CD8 levels, indicating possibilities of SARS-COV-2 virus directly infects lymphocytes, which is eventually represented in dysfunctional antiviral effect [14]. Reactivation of $\mathrm{HZ}$ is infrequent in covid-19 patients, but few cases raised the concerns of the possible association. A reported two cases pustules that $\mathrm{HZ}$ reactivation preceding the emergence of typical symptoms of COVID19 [15]. Moreover, HZ may occur in entirely asymptomatic COVID19 patients [16]. In our case, the patient developed $\mathrm{HZ}$ three days after presenting with prodromal symptoms. It is to

Website: https://www.banglajol.info/index.php/UpDCJ 
mention that during the pandemic situation a patient's manifestation with $\mathrm{HZ}$ aware health care worker to rule out the COVID-19 and applying maximum protocol of management that fulfill the national guideline of the country.

\section{CONCLUSION:}

We presented a case of an immunocompetent middle-aged male who was visited as a case of COVID-19 in combination with $\mathrm{HZ}$. The case postulates an association between COVID19 and reactivation of VZV in the form of $\mathrm{HZ}$. In patients who present with $\mathrm{HZ}$ in the current pandemic of COVID-19, we believe it would be prudent to adhere to maximum precautions until the diagnosis of COVID-19 is excluded.

\section{CONFLICT OF INTEREST: None.}

PATIENT CONSENT: Author proclaimed and submitted the consent form for image and profile sharing for research and journal publishing.

\section{Citation:}

Abdullah Al Faruk, \& Mohammad Rifat Rahman. Herpes Zoster associated With COVID-19 in an immunocompetent male. Update Dental College Journal, 11(2), 35-37. https://doi.org/10.3329/updcj.v11i2.56096

\section{REFERENCES}

1. Saati A, Al-Husayni F, Malibari A A, et al. (July 04, 2020) Herpes Zoster Co-Infection in an Immunocompetent Patient with COVID19. Cureus 12(7): e8998. doi:10.7759/cureus.8998 https://doi.org/10.7759/cureus.8998

2. Islam TM et al, Tackling the COVID-19 pandemic: The Bangladesh perspective 2020 Oct 14; 9(4):1794. doi: 10.4081/jphr.2020.1794 https://doi.org/10.4081/jphr.2020.1794 PMid:33117758 PMCid:PMC7582102

3. Early transmission dynamics in Wuhan, China, of novel coronavirus-infected pneumonia. Li Q, Guan X, Wu P, et al. N Engl J Med. 2020;382:1199-1207. [PMC free article] [PubMed] [Google Scholar]

4. Sachdeva M, Gianotti R, Shah M, et al.: Cutaneous manifestations of COVID-19: report of three cases and a review of the literature. J Dermatol Sci. 2020, 98:75-81. 10.1016/j.jdermsci.2020.04.011 https://doi.org/10.1016/i.jdermsci.2020.04.011 PMid:32381430 PMCid:PMC7189855

5. Dworkin $\mathrm{RH}$, Johnson RW, Breuer J, et al.: Recommendations for the management of herpes zoster. Clin Infect Dis. 2007, 44:1-26. $10.1086 / 510206$

6. Wung PK, Holbrook JT, Hoffman GS, et al: Herpes zoster in immunocompromised patients: incidence, timing, and risk factors. Am J Med. 2005, 118:1416. 10.1016/j.amjmed.2005.06.012 https://doi.org/10.1016/j.amjmed.2005.06.012 PMid:16378799

7. Johnson RW, Alvarez-Pasquin MJ, Bijl M, et al.: Herpes zoster epidemiology, management, and disease and economic burden in

37|P a g e
Europe: a multidisciplinary perspective. Ther Adv Vaccines. 2016 4:109-120. https://doi.org/10.1177/2051013615599151 PMid:26478818 PMCid:PMC4591524

8. Hayward AR, Herberger M: Lymphocyte responses to varicellazoster virus in the elderly. J Clin Immunol. 1987, 7:174-178. 10.1007/BF00916011 https://doi.org/10.1007/BF00916011 PMid:3033012

9. Cohen JI: Clinical practice: herpes zoster. N Engl J Med. 2013, 369:255-263. https://doi.org/10.1056/NEJMcp1302674 PMid:23863052 PMCid:PMC4789101

10. Siddiqi HK, Mehra MR: COVID-19 illness in native and immunosuppressed states: a clinical-therapeutic staging proposal. $J$ Heart Lung Transplant. 2020, 39:405-407. 10.1016/j.healun.2020.03.012

https://doi.org/10.1016/j.healun.2020.03.012 PMid:32362390 PMCid:PMC7118652

11. Rittirsch D, Flierl MA, Ward PA: Harmful molecular mechanisms in sepsis. Nat Rev Immunol. 2008, 8:776-787. 10.1038/nri2402 https://doi.org/10.1038/nri2402 PMid:18802444 PMCid:PMC2786961

12. Goodwin AJ, Rice DA, Simpson KN, Ford DW: Frequency, cost, and risk factors of readmissions among severe sepsis survivors. Crit Care Med. 2015, 43:738-746. 10.1097/CCM.0000000000000859 https://doi.org/10.1097/CCM.0000000000000859 PMid:25746745 PMCid:PMC4479267

13. Henry BM, de Oliveira MHS, Benoit S, Plebani M, Lippi G: Hematologic, biochemical and immune biomarker abnormalities associated with severe illness and mortality in coronavirus disease 2019 (COVID- 19): a meta-analysis. Clin Chem Lab Med. 2020, 58:1021-1028 $10.1515 / \mathrm{cclm}-2020-0369$ https://doi.org/10.1515/cclm-2020-0369 PMid:32286245

14. Zheng $M$, Gao $Y$, Wang G, et al.: Functional exhaustion of antiviral lymphocytes in COVID-19 patients. Cell Mol Immunol. 2020, 17:533-535. 10.1038/s41423-020-0402-2 https://doi.org/10.1038/s41423-020-0402-2 PMid:32203188 PMCid:PMC7091858

15. Elsaie ML, Youssef EA, Nada HA: Herpes zoster might be an indicator for latent COVID 19 infection. Dermatol Ther. 2020 e13666. https://doi.org/10.1111/dth.13666 PMCid:PMC7267085

16. de Freitas Ferreira ACA, Romão TT, Sllva Macedo $Y$, Pupe $C$, Nascimento OJ: COVID-19 and herpes zoster co-infection presenting with trigeminal neuropathy. Eur J Neurol. 2020, 10.1111/ene. 14361 https://doi.org/10.1111/ene.14361 PMid:32449248 PMCid:PMC7283788

Website: https://www.banglajol.info/index.php/UpDCJ 